Organisation Ecotouristique du Lac Oguemoué began surveys of the Lambaréné bushmeat market in 2012, the Critically Endangered slender-snouted crocodile Mecistops cataphractus was the most commonly observed bushmeat for sale. Between 2012 and 2015 slender-snouted crocodile bushmeat represented over half of all bushmeat from protected species recorded in market and restaurant surveys. Although the slender-snouted crocodile has been fully protected under national law in Gabon since 2011, local hunters, vendors, restaurant owners and consumers either did not fear law enforcement or did not understand that the species was protected, because they continued to openly advertise crocodile meat on restaurant menus and bushmeat tables.

In 2015 the Organisation launched an outreach campaign in Lambaréné-Projet Faux Gavial (Project slender-snouted crocodile) - to raise awareness about the species, rally pride for crocodile conservation, encourage local leaders and law enforcement to enforce laws, and change the preferences of the next generation of bushmeat consumers. Between October 2015 and September 2016 the Projet Faux Gavial team presented an environmental education curriculum on crocodiles at 14 local schools, launched student-led nature clubs that engaged in outreach about crocodile conservation, led community outreach with hunters and vendors at the local market, created a community green space with a crocodile mural, erected an informative panel on the protected status of the crocodile at the bushmeat market, and worked closely with local leaders to find ways to reduce commerce. As a result of these efforts, in February 2015, the Mayor of Lambaréné signed a decree forbidding the commerce of protected species in the city and pledging support to enforce protected species laws. In early 2016 the project team launched a citizen science project in which students use WhatsApp to record slender-snouted crocodile sightings and crocodile bushmeat for sale. The most active students in this effort will win scholarships for the upcoming school year.

Organisation Ecotouristique du Lac Oguemoué compiles biannual market surveys, at the opening and closing of each annual hunting season (March and September of each year). For the first time in 4 years of surveys the team found no slender-snouted crocodile bushmeat for sale during the closed hunting season of September 2015-March 2016 and only $4 \%$ of restaurant surveys included slender-snouted crocodile meat for sale. In comparison, during the previous closed hunting season (September 2014-March 2015), $27 \%$ of market surveys recorded slender-snouted crocodile meat for sale and $61 \%$ of restaurant surveys recorded slender-snouted crocodile stew on the daily menu. During the open hunting season of March-Sept 2016 no slender-snouted crocodiles were recorded on bushmeat tables and only two incidences of crocodile meat for sale were recorded in restaurants.
These early successes are promising but the team will need to maintain momentum to ensure that commerce does not restart or go onto the black market. In the forthcoming months the team will be looking for any black markets, identifying livelihood alternatives to hunting and selling crocodiles, and collaborating with local community leaders, including market representatives, teachers, law enforcement, conservation partners, elected leaders and religious leaders to keep this Critically Endangered crocodile off the bushmeat table and out of cooking pots.

We thank the Conservation Leadership Programme and the USFWS Wildlife Without Borders Program for their support. For more information on this project and the other work of Organisation Ecotouristique du Lac Oguemoué, see www.oelogabon.org.

Heather Arrowood and Cyrllle Mvele Organisation Ecotouristique du Lac Oguemoué, Libreville, Gabon E-mail hcarrowood@yahoo.fr

\section{Evaluating the impacts of conservation interventions on human well-being: guidance for practitioners}

New guidance has been developed to help conservationists evaluate the impacts of their interventions on human well-being. Published by the International Institute of Environment and Development, these guidelines draw on insights provided by a wide range of conservation practitioners, academics and funding bodies for navigating the methodological decisions to be made in developing an evaluation strategy for a wide variety of situations. The document draws on robust scientific approaches while taking into account practical issues.

Conservationists are increasingly recognizing the importance of evaluating their impacts, to ensure accountability and to learn what works and what doesn't. As part of this, they are increasingly interested in impacts on human wellbeing because of the moral imperative to at the very least do no harm and, pragmatically, a growing number of conservation strategies rely on improved livelihoods or other positive social outcomes. Although a number of social impact evaluation tools and methods have been designed, by both academics and conservationists, no single tool or method will work for every intervention. Therefore, instead of providing another evaluation method, these guidelines aim to provide an understanding of the different steps and issues that are involved in social impact evaluation. They aim to enable conservationists to make the right decisions, and signpost appropriate methods and tools along the way. In particular, the guidelines aim to help small NGOs consider why they wish to evaluate their social impacts, and what is feasible given their funding and capacity constraints. 
Practitioners should be clear on the purpose and aims of evaluation, as different methods are required to answer different questions. For example, those wishing to demonstrate and measure how successful a project has been to funders may prefer to use study designs that make use of comparisons to an unaffected site. Those looking to learn from their experiences and understand how and why impacts occurred may prefer a more thorough investigation of the causal processes using a theory-based design. These differences should be considered at an early stage in the design of evaluation. Interventions vary, not only in the resources, budgets and technical skills available, but also in their intrinsic attributes. The length of a project, and timescales of impacts, geographical scale, the availability of controls and the social, political and cultural contexts should all influence design of evaluation.

Whether you are a working conservationist trying to design an evaluation strategy or a funding body requesting evidence of impact, these guidelines will help you to make sense of the complex landscape of evaluation design and understand the methodological options that are available. The guidelines are freely available and can be found at http://pubs.iied.org/14667IIED. Feedback is welcome.

EMIEL DE LANGE School of Geosciences, University of Edinburgh, Edinburgh, UK and Department of Life Sciences, Imperial College London, London, UK

E-maile.delange@ed.ac.uk

EMILY Woodhouse Department of Anthropology, University College London, London, UK

E.J. Milner-Gulland Department of Zoology, University of Oxford, Oxford, UK

\section{Confirmation of free-ranging Barbary sheep Ammotragus lervia in Dghoumes National Park and Boukornine National Park, Tunisia}

Like most of the wild ungulates that were once widespread in North Africa, populations of the Barbary sheep Ammotragus lervia have declined as result of overhunting and habitat fragmentation, and the species is now categorized as Vulnerable on the IUCN Red List. The Barbary sheep, or aoudad, occurred historically in the mountains of central and southern Tunisia, but threats to its persistence across the country have been noted for more than half a century (H.W. Schomber \& D. Kock, 1960, African Wildlife, 14, 277-282.). Today, a reintroduced population of Barbary sheep reportedly persists in the Chambi National Park, some individuals have been released into the protected confines of the Oued Dekouk National Reserve, and small numbers are held in captivity at various locations. There is, however, little information about the status of the species across most of its supposed range in Tunisia, and at a workshop in May 2014, organized by the IUCN Centre for Mediterranean Cooperation, with the support of Tunisia's Forestry Directorate and Ministry of Environment, to discuss the conservation of Barbary sheep in Tunisia, participants acknowledged the need to gather more data about this species.

Previously, Barbary sheep were regularly seen in the mountains bordering the northern limits of the Chott El-Jerid, a large salt lake in southern Tunisia (A. Chetoui, pers. obs.; K. de Smet, 1997, In Wild Sheep and Goats and Their Relatives: Status Survey and Conservation Action Plan for Caprinae, pp. 45-47, IUCN, Gland, Switzerland). However, in surveys since 2012 we have noted a significant diminution in signs of the species. In response, personnel from Dghoumes National Park intensified surveillance in the mountains, reporting tracks of Barbary sheep in early 2016. Two camera traps were subsequently deployed for 66 days during March-May 2016. Barbary sheep were recorded four times, confirming the presence of at least five individuals: a mature male accompanied by a young adult of unknown sex, a second mature male and a juvenile, and a solitary mature animal of unknown sex recorded twice, 5 days apart.

We similarly increased survey effort in Boukornine National Park, near Tunis, in the northerly part of the species' Tunisian range. Barbary sheep were photographed on 10 occasions during 13 days of camera trapping in February 2016. Between one and eight animals were recorded in these images at two locations, adding to opportunistic sightings of at least three individuals within this protected area in 2015 (Marwell Wildlife, unpubl. data).

Confirmation of the presence of Barbary sheep of various ages in two locations in Tunisia is welcome news, particularly in light of the lack of other recent sightings and fears of local extinctions. However, questions about the size, distribution and connectivity of these populations remain. The mountainous habitats within and adjacent to protected areas such as Dghoumes and Bou Hedma National Parks are logical places to focus further attention. Through the continuing collaboration between Marwell Wildlife and the Tunisian Forest Directorate, we are working to improve conservation efforts in Tunisia's protected areas for the benefit of numerous threatened species, including Barbary sheep. Efforts to improve connectivity between protected areas is a key objective, although one that presents many problems, which we are working together to solve.

M. Petretto, A. Chetoui, C. NajJar, T. Woodfine and P. RIORDAN Marwell Wildife, Colden Common, Winchester, Hampshire, UK. E-mail mariep@marwell.org.uk 